\title{
Assessing Bank Competition in Nepal Using Panzar-Rosse Model
}

\author{
Prem Bahadur BUDHATHOKI ${ }^{1}$, Chandra Kumar RAI ${ }^{2}$, Arjun RAI ${ }^{3}$
}

Received: August 01, 2020 Revised: October 05, 2020 Accepted: October 15, 2020

\begin{abstract}
The purpose of this study is to assess the state of competition in Nepalese banking over the period from 2010 to 2019 . This study employs panel data and a non-structural Panzar-Rosse model to measure the degree of competition in the Nepalese banking industry. The first reduced-form equation is applied to gauge competition, and the second model is used to test the long-run equilibrium in the banking market. The finding reveals that the Nepalese banking market is equilibrium in the long-run. It implies that the factor prices do not affect ROA in the long-run. The result of the H-statistic shows that the Nepalese banking system is operating under the state of perfect competition and is shifted from monopolistic competition to perfect competition. The reduced-form model reveals that the interest income is positive and significantly affected by factor prices. Similarly, the macroeconomic variable GDP growth is positively related to interest income. On the contrary, the bank's specific factors risk and the number of bank branches are inversely associated with the regressand. The outcomes of the study may be advantageous to the policymakers, especially to Nepal Rastra Bank to implement monetary policy and M\&A policy for the stability and growth of the financial system of Nepal.
\end{abstract}

Keywords: Bank Competition, Panzar-Rosse Model, Market Equilibrium, Panel Data

JEL Classification Code: C33, G21, L11, N25

\section{Introduction}

The Nepalese banking sector has operated a paradigm shift from monopoly to monopolistic competition after adopting privatization, liberalization, and deregulation policy in the 1990s, which changes the overall scenario of the banking industry in Nepal. In recent years, commercial banks (CBs), development banks, finance companies, and micro-finance companies are fiercely competing to grab a higher market share. These four types of depository institutions look alike because they perform similar types of work (i.e., accept deposit and provide loans) and sell similar

${ }^{1}$ First Author. Lecturer, Finance Department, Mahendra Multiple Campus, Tribhuvan University, Nepal.

Email: prem.budhathoki@mahmc.tu.edu.np

${ }^{2}$ Corresponding Author. Associate Professor, Finance Department, Mahendra Multiple Campus, Tribhuvan University, Nepal [Postal

Address: Dharan-11, Sunsari, Dharan, Province-1, Nepal]

Email: chandra.rai@mahmc.tu.edu.np

${ }^{3}$ Lecturer, Management Department, Mahendra Multiple Campus,

Tribhuvan University, Nepal. Email: arjun.rai@mahmc.tu.edu.np

(c) Copyright: The Author(s)

This is an Open Access article distributed under the terms of the Creative Commons Attribution Non-Commercial License (https://creativecommons.org/licenses/by-nc/4.0/) which permits unrestricted non-commercial use, distribution, and reproduction in any medium, provided the original work is properly cited. types of service products. There is no consensus about the effect of competition on firms' performance, stability, and growth. There are two conflicting views regarding the impact of bank competition on the risk-taking behavior of the bank. The conventional 'competition-fragility' view contends that fierce competition deteriorates market power, thereby reduces profit margins and franchise value of banks. It ultimately raises the risk-taking behavior of the banks. On the contrary, the modern 'competition-stability' view argues that a low level of competition poses high default loss because, in a less competitive market, the bank charges a higher interest rate to the borrowers, which ultimately makes it difficult to repay interest and principal amount on time. Besides this, it increases moral hazard problems from the side of borrowers and adverse selection problems from the side of lenders (Berger et al., 2009).

Similarly, there are three contrasting views concerning the impact of competition on the economic growth of the nation. The first view emphasizes that the degree of competition (high concentration) limits the firm's access to finance. The second view contends that, in a highly concentrated market, banks play the role of information disseminator and maintain a good relationship with their customers. On the contrary, a highly competitive market leads to the asymmetry of information (Khan et al., 2018). 
Furthermore, high competition compels banks to relax their credit standard, which ultimately increases the bank's credit risk. The traditional risk-return hypothesis states that a higher risk requires a higher rate of return. When interest rates rise, the project becomes less viable and decreases the economic growth rate. However, the competition not only brings a threat, but it also brings opportunities; banks need to develop advance technical and managerial skills to survive in the competitive world (Hou et al., 2014). Also, a higher level of competition enhances the quality and menu of service products, increase market share and improves the overall efficiency of the banks. It reduces the operating costs, enhances customers' service, and is improve the overall performance of the banking industry in the long-run (Homma et al., 2014; Misra \& Arrawatia, 2015; Rakshit \& Bardhan, 2020). The fierce competition in the banking sector also opens the door to diversify assets from traditional loan business to non-traditional fee and commission generating assets. This diversified revenue sources can be used to compensate for the default loss arising from low loan quality (Ahamed, 2017). Conversely, the failure of banks and financial institutions bring a contagion effect in the whole financial system. It further erodes public confidence and raises social cost. The third line of arguments and empirical shreds of evidence indicates that the relationship between financial development and economic growth rate is U-shaped (Tariq et al., 2020).

The empirical findings of the link between bank performance and competition can be grouped into three categories. The first line of the practical conclusions contends that more degree of competition positively impacts on cost efficiency and profitability of the banks. However, they undertake a higher level of risk (Fang et al., 2019). Further, it enables banks to obtain a higher market share and leads to higher market concentration (Khan et al., 2017). The second line of empirical findings support the relative market power hypothesis and contend that a bank having a higher market share can grab a higher return by charging higher prices. However, they become less efficient (Gonzalez et al., 2019). The third line of empirical evidence stated that the nexus between bank competition and credit risk would be U-shaped. "Up to a certain threshold, higher levels of bank competition are associated with lower risk. Above this threshold, more competition increases credit risk" (Brei et al., 2020).

Though there are conflicting issues regarding the importance of bank competition in the economy, from the viewpoint of consumers, they can get the loan and other service products at a reasonable price. From the perspective of policymakers, competition increases the efficiency of banks, lower the lending rate, and improve the overall performance of the economy.

The appraisal of bank's contestability will facilitate policymakers in designing appropriate monetary, risk management, M\&A, access to finance, safety of depositors' funds, and new entry norms policies. Therefore, this paper yields a threefold contribution. First, this paper fills a vacuum in the existing body of literature by supplying facts on the state of competition in the Nepalese banking industry. In recent years, this affair does not address in the current literature on bank competition in Nepal. Second, this study gauges the competitive condition of the Nepalese banking sector by using the non-structural Panzar-Rosse (P-R) model. Third, this study attempts to justify the relevance of M\&A by examining the size effect on the bank's revenue.

The overall research plan of this paper is as follows: Section 2 reviews the theoretical, conceptual, and recent empirical findings; Section 3 presents data, and empirical models; Section 4 exhibits the results; Section 5 describes the empirical findings; and the final section ends with a conclusion.

\section{Literature Review}

The literature on the condition of bank competition in neighboring countries like China, India, Pakistan, Bangladesh, and other developed economies has been extensively investigated in several studies. However, very few studies were conducted about the competition of CBs in Nepal. There are two major conflicting hypotheses regarding the relationship competition and performance of the banks. On the one hand, the traditional structureconduct-performance theory states that a higher market concentration (low degree of competition) produces a better performance of the banks. The reason behind this argument is that a fewer number of banks can realize an enormous profit by imposing high-interest rates on credit and offer low-interest rates on deposits, which ultimately raises the net interest income and leads to better performance. A large body of studies was made to test the relationship between bank competition and banks' performance. For example, by taking the sample of 20 Pakistani CBs from 1994 through 2004, Ali Bhatti and Hussain (2010) conducted research and found a negative relationship between bank competition and profitability. A higher degree of bank competition increases the banks' non-performing loans and decreases the overall profitability (Rachman et al., 2018; Tangngisula et al., 2020). Nevertheless, the credit risk of the banks might depend on the structure of lending portfolio (Le \& Diep, 2020).

On the other hand, the efficiency-hypothesis insists that the outcome of an individual bank solely depends on the bank's degree efficiency (Samad, 2008). When a bank can produce a better-quality product at a reasonable price as compared to its major competitors, then the bank may be able to maximize market shares and profits. In this connection, Samad (2008) conducted a study using pooled data from 1999 to 2002 and support the efficiency hypothesis. 
The empirical evidence on the bank competition has been broadly categorized into two parts-structural and non-structural. The structural model to measure bank competition has certain limitations. The non-structural P-R model is mostly used by the researcher "due to its modest data requirement, simple econometric specification, and validation of long-run market equilibrium" (Rakshit \& Bardhan, 2020). A large body of studies used this model to ascertain the degree of bank competition in our neighboring countries. However, very few studies were made in the context of Nepal. As per our own best knowledge, the first study about the bank competition in Nepal was conducted by Gajurel and Pradhan in 2012, taking an unbalanced panel data of 15-25 CBs over the period 2001-2009. They used structural and non-structural approaches to assess the level of competition in Nepal. The findings of P-R H-statistic showed that the Nepalese CBs had been working under monopolistic competition. Again, Neupane (2016) look into the degree of competition in Nepalese CBS. The findings of the study using the P-R model showed that Nepalese CBs were operating under the condition of monopolistic completion. This result was in line with the findings of Gajurel and Pradhan (2012). Other significant findings of different studies are presented in Table 1.

Established along with the aforementioned empirical evidence, the priory expectation about the degree of competition in Nepalese CBS is monopolistic competition.

\section{Method}

We examined the present competitive condition of CBs in Nepal by taking annual data of nine sampled CBs from 2010 to 2019. In this study, all the $27 \mathrm{CBs}$ operating in Nepal were considered the population of the study. This study was based on the panel data over the period from 2010 to 2019. Therefore, 90 observations were made in total. These data were collected from the Bank Supervision Report, published by Nepal Rastra Bank (Central bank of Nepal).

For this purpose, we used the natural logarithm of interest income as a regressand. And the other seven variables were taken as regressors. The first regressor was a log of labor cost, which was measured by taking the natural log of employee expenses over total assets. The second regressor was the natural logarithm of capital cost, which was calculated by taking the natural logarithm of the sum of administrative cost, depreciation, and other operating costs over the total assets of a particular bank. The third regressor was a log of funding cost, which was measured by taking the natural logarithm of interest expenses over total assets. The fourth regressor was the natural logarithm of risk, which was calculated by taking a log of provision for loan losses over total loan and advances.

Table 1: Empirical finding on banks competition- The P-R model

\begin{tabular}{|c|c|c|c|c|}
\hline Authors & Period & Data & Country & Findings \\
\hline Matthews et al. (2007) & $1980-2004$ & Panel & UK & Monopolistic Competition \\
\hline Akthan and Masood (2010) & $1998-2010$ & Panel & Turkey & Monopolistic Competition \\
\hline Biekpe (2011) & $2000-2007$ & Panel & Ghana & Monopolistic Competition \\
\hline Fosu (2013) & $2002-2013$ & Panel & African countries & Monopolistic Competition \\
\hline Hall and Simper (2013) & 2007-2011 & Panel & South Korea & Perfect Competition \\
\hline Simatele (2015) & $1997-2014$ & Panel & South Africa & Monopolistic Competition \\
\hline Apergis (2015) & 2002-2012 & Panel & Cross-country & Monopolistic Competition \\
\hline Sarkar and Sensharma (2016) & $2000-2013$ & Panel & India & Monopolistic Competition \\
\hline Barros and Mendes (2016) & $2005-2014$ & Panel & Angola & Monopolistic Competition \\
\hline Tan (2016) & $2003-2013$ & Panel & China & Monopolistic Competition \\
\hline Osuagwu and Nwokoma (2017) & $2005-2017$ & Panel & Nigeria & Monopolistic Competition \\
\hline Tihir et al. (2017) & $2007-2015$ & Panel & Pakistan & Monopolistic Competition \\
\hline Khan et al. (2018) & $1994-2014$ & Panel & China & Monopolistic Competition \\
\hline Kumar and Gulati (2019) & $1999-2016$ & Panel & India & Closer to perfect competition \\
\hline Rakshit and Bardhan (2020) & 1996-2016 & Panel & India & Monopolistic Competition \\
\hline
\end{tabular}


Also, this measured the default risk of the banks. The fifth regressor was the natural logarithm of the size of banks, which was measured by taking the natural $\log$ of total assets. The sixth regressor was the natural log of the number of bank branches over the total number of bank branches of all the banks. The final regressor was a log of growth rate, which was measured by taking the natural logarithm of the annual GDP growth rate. In the equilibrium test regression model, the natural logarithm of ROA was used as a regressand. Further, ROA was calculated, dividing net income after taxes by total assets of the banks.

This study employed the P-R model to examine the competitive condition of CBs in Nepal. The P-R H-statistic is applied to confirm the direction of revenue change to change in input prices. In other words, when total revenue and input prices move in the same direction, this will show a competitive market (Hall \& Simper, 2013). The P-R model is a non-structural measure of bank competition, which was popularized by P-R (1987). It is based on reduced- form revenue equation (Fosu, 2013). The empirical evidence is shown by the P-R H-statistic, which is the sum of the elasticity of revenues to input prices. According to the P-R model, the revenue and the cost function are as follows;

$$
\begin{aligned}
& \mathrm{R}_{\mathrm{i}}=\mathrm{R}_{\mathrm{i}}\left(\mathrm{y}_{\mathrm{i}}, \mathrm{n}, \mathrm{Z}_{\mathrm{i}}\right) \\
& \mathrm{C}_{\mathrm{i}}=\left(\mathrm{y}_{\mathrm{i}}, \mathrm{w}_{\mathrm{i}}, \mathrm{x}_{\mathrm{i}}\right)
\end{aligned}
$$

Where $\mathrm{R}_{\mathrm{i}}$ symbolizes for total revenue, $\mathrm{C}_{\mathrm{i}}$ symbolizes for the total cost, $\mathrm{y}$ symbolizes for output, $\mathrm{n}$ symbolizes for the number of banks, $\mathrm{Z}$ symbolizes for exogenous variables that affect revenue, $\mathrm{w}_{\mathrm{i}}$, symbolizes for input prices, and $\mathrm{x}_{\mathrm{i}}$ symbolizes for exogenous variables.

The maximum profit can be achieved in long-run when $\mathrm{MR}$ is equal to $\mathrm{MC}$.

Table 2: Explanation of $\mathrm{H}$-statistic

\begin{tabular}{|l|l|l|}
\hline Outcomes & \multicolumn{1}{|c|}{ Results } & \multicolumn{1}{c|}{ Explanations } \\
\hline $\begin{array}{l}\mathrm{H} \leq 0 \\
\text { (Al-Muharrami } \\
\text { et al., 2006) }\end{array}$ & Monopoly & $\begin{array}{l}\text { Revenue will change in } \\
\text { the opposite direction with } \\
\text { a change in input prices. }\end{array}$ \\
\hline $\begin{array}{l}0<\mathrm{H}<1 \\
\text { (Al-Muharrami } \\
\text { et al., 2006) }\end{array}$ & $\begin{array}{l}\text { Monopolistic } \\
\text { competition }\end{array}$ & $\begin{array}{l}\text { Revenue will change in } \\
\text { the same direction with } \\
\text { a change in input prices. } \\
\text { but income will change by } \\
\text { fewer amounts than input } \\
\text { prices. }\end{array}$ \\
\hline $\begin{array}{l}\mathrm{H}=1 \\
\text { (Al-Muharrami } \\
\text { et al., 2006) }\end{array}$ & competition & $\begin{array}{l}\text { Revenue will change in } \\
\text { the same direction and by } \\
\text { the same amount with a } \\
\text { change in input prices. }\end{array}$ \\
\hline
\end{tabular}

$$
\operatorname{Profit}(\pi)=\mathrm{R}_{\mathrm{i}}\left(\mathrm{y}_{\mathrm{i}}, \mathrm{n}, \mathrm{Z}_{\mathrm{i}}\right)-\left(\mathrm{y}_{\mathrm{i}}, \mathrm{W}_{\mathrm{i}}, \mathrm{X}_{\mathrm{i}}\right)=0
$$

The profit in the equilibrium market;

$$
\mathrm{R}_{\mathrm{i}}\left(\mathrm{y}^{*}, \mathrm{n}^{*}, \mathrm{Z}\right)-\left(\mathrm{y}^{*}, \mathrm{w}_{\mathrm{i}}, \mathrm{x}_{\mathrm{i}}\right)=0
$$

The value of P-R H-statistic is derived as the sum of the elasticity of $\mathrm{k}$ input prices. That is

$$
\mathrm{H}=\sum_{k=1}^{k}\left(\frac{\partial R_{i}^{*}}{\partial W_{k}}\right)\left(\frac{W_{k}}{R_{i}^{*}}\right)
$$

The reduced form equation to measure bank competition is;

$$
\begin{aligned}
\operatorname{lnII}_{\mathrm{it}} & =\alpha_{0}+\alpha_{1} \operatorname{lnLC}_{\mathrm{it}}+\alpha_{2} \operatorname{lnCC}_{\mathrm{it}}+\alpha_{3} \operatorname{lnFC} \mathrm{lit}_{\mathrm{it}} \\
& +\beta_{1} \operatorname{lnRISK} \mathrm{lit}_{\mathrm{it}}+\beta_{2} \operatorname{lnTA_{\mathrm {it}}}+\beta_{3} \ln \mathrm{lR}_{\mathrm{it}} \\
& +\gamma_{1} \operatorname{lnGR}_{\mathrm{it}}+\mathrm{u}_{\mathrm{it}}
\end{aligned}
$$

Where II designates for interest income of the banks, LC is the ratio of personnel expenses (or staff expenses) to total assets; FC is the ratio of interest expenses to total assets; CC is the ratio of cost of capital to total assets; RISK is the ratio of provision for loan losses to loan and advances; TA is the size of firms in term of total assets; BR is the ratio of the bank's branches to the total number of bank branches for all banks, and growth rate indicates the annual growth rate of GDP.

The outcome of H-statistic is interpreted as follows;

However, the Panzar-Rosse Model is applicable only in the banking sector when it holds long-run equilibrium in the market. Therefore, we employed the equilibrium regression model to test the long-run equilibrium.

$$
\begin{aligned}
\operatorname{lnROA}_{\mathrm{it}} & =\alpha_{0}^{\prime}+\alpha_{1}^{\prime} \operatorname{lnLC}_{\mathrm{it}}+\alpha_{2} \ln \mathrm{ln}_{\mathrm{it}}+\alpha_{3}^{\prime} \operatorname{lnFC} \mathrm{It}_{\mathrm{it}} \\
& +\beta_{1}^{\prime} \operatorname{lnRISK_{it}}+\beta_{2} \operatorname{lnTA}_{\mathrm{it}}+\beta_{3}^{\prime} \ln \mathrm{ln}_{\mathrm{it}} \\
& +\gamma_{1}^{\prime} \operatorname{lnGR}_{\mathrm{it}}+\mathrm{u}_{\mathrm{it}}
\end{aligned}
$$

The above equilibrium regression model used the natural logarithm of return on assets (lnROA) as regressand, and it is argued that the equilibrium condition exists in the market when $\alpha_{1}^{\prime}+\alpha_{2}^{\prime}+\alpha_{3}^{\prime}=0$.

The regression diagnostic has carried-out to detect multicollinearity, normality, heteroscedasticity, and autocorrelation by VIF, Jarque-Bera test, Breusch-Pagan test, and Durbin-Watson test, respectively. The Wald-test was administered to check the statistical significance of the $\mathrm{H}$-statistic and equilibrium test. Further, the Chow-test has performed to decide the selection of whether a pooled OLS or fixed effect model (FEM) was appropriate. Similarly, Hausman-test has drawn to decide the selection of whether a FEM or random effect model (REM) was appropriate. Finally, LM-test has governed to select whether a REM or pooled OLS was appropriate. 


\section{Results}

Table 3 showed the results of descriptive statistics. The average values of regressors such as labor cost, capital cost, funding costs, risk, bank's size, bank's geographical diversification, macroeconomic variables GDP growth rate in terms of natural logarithm were $.0507,-.360,1.630,-.802$, $11.214,1.120$, and 1.272 respectively. Indeed, the average value of regressand interest income in terms of natural logarithm was 8.517 . The variability, which was measured by SD showed that credit risk was more volatile than that of other regressand and regressors. The SD of other regressors such as $\operatorname{lnLC}, \operatorname{lnCC}, \operatorname{lnFC}, \operatorname{lnRISK}, \operatorname{lnTA}, \ln B R$, and $\operatorname{lnGR}$ was $.609, .433, .603,1.143, .708$, and 1.009 respectively. Finally, the SD of lnII was .538.

Table 4 depicted the correlation matrix of regressand and regressors. Before carrying out the regression analysis, we needed to check the existence of a multicollinearity problem in the regressors. The correlations among the research variables described in the model were presented in Table 4. According to a rule of thumb, almost all the correlation coefficient among regressors was found to be less than .7 except between $\operatorname{lnCC}$ and $\operatorname{lnTA}$. Further, the VIF of regressors showed that there was no trouble of multicollinearity to handle the regression model.
Table 5 revealed the outcomes of regression diagnostics and regression coefficients. The result of the Jarque-Bera test for normality showed that this distribution was normal. The Breusch-Pagan test for homoscedasticity revealed that this distribution was homoscedastic. The choice between pooled OLS and FER was carried out by conducting the Chow test. The null hypothesis was that pooled OLS was better than FEM, indicating that FEM is superior to that of pooled OLS.

Similarly, the selection between the FEM and the REM was made by conducting the Hausman test, indicating that REM was more appropriate than that of FEM. Further, the choice between OLS and REM is made by performing LM test, telling that the REM was superior that the OLS model. Finally, we applied the REM to analyze the bank competition in Nepal using the P-R model. The R-square and adjusted $\mathrm{R}$-square were found .826 and .813 , and the fitted model was also found highly significant $(\mathrm{F}=56.202, \mathrm{p}=.000)$. The main results of regression analysis based on REM with additional information are provided below. The Wald test has been used to test the two hypotheses of monopoly competition $(\mathrm{H}=0)$ and perfect competition $(\mathrm{H}=1)$. The outcomes showed that the idea of a monopoly market structure is rejected at the $1 \%$ significance level, and the evidence has not rejected the view of perfect competition.

Table 3: Summary statistics

\begin{tabular}{|c|c|c|c|c|}
\hline Variables & Minimum & Maximum & Mean & SD \\
\hline InII & 7.060 & 9.630 & 8.517 & .538 \\
\hline $\operatorname{lnLC}$ & -1.070 & 3.210 & .0507 & .609 \\
\hline $\operatorname{lnCC}$ & -1.350 & 2.680 & -.360 & .433 \\
\hline $\operatorname{lnFC}$ & .560 & 5.840 & 1.630 & .630 \\
\hline InRISK & -5.010 & 2.700 & -.802 & 1.143 \\
\hline $\ln T A$ & 8.300 & 12.350 & 11.214 & .648 \\
\hline InBR & -1.280 & 2.570 & 1.120 & .708 \\
\hline InGR & -1.610 & 2.050 & 1.272 & 1.009 \\
\hline
\end{tabular}

Table 4: Correlations

\begin{tabular}{|c|c|c|c|c|c|c|c|c|}
\hline Variables & InII & InLC & InCC & InFC & InRISK & InTA & InBR & InGR \\
\hline InII & 1 & .084 & $-.373^{* *}$ & -.172 & $-.234^{*}$ & $.806^{\star *}$ & $.283^{* *}$ & .170 \\
\hline $\operatorname{lnLC}$ & & 1 & $.351^{* *}$ & $-.274^{\star *}$ & -.020 & -.178 & .206 & .144 \\
\hline $\ln C C$ & & & 1 & .151 & $.231^{*}$ & $-.739^{* *}$ & $.302^{* *}$ & .036 \\
\hline $\operatorname{lnFC}$ & & & & 1 & $.376^{\star \star}$ & $-.288^{* *}$ & .047 & $.275^{\star \star}$ \\
\hline InRISK & & & & & 1 & -.190 & $.220^{*}$ & -.020 \\
\hline $\operatorname{lnTA}$ & & & & & & 1 & $.388^{* *}$ & -.022 \\
\hline InBR & & & & & & & 1 & -.048 \\
\hline $\ln G R$ & & & & & & & & 1 \\
\hline
\end{tabular}

Note: ${ }^{* * *},{ }^{* *}$, and ${ }^{*}$ denote significant at $1 \%, 5 \%$, and $10 \%$ level of significance. 
Table 5: Random effect model

\begin{tabular}{|c|c|c|c|c|c|}
\hline Variables & Coefficients & S.Errors & t-statistics & P-value & VIF \\
\hline InLC & $.246^{* * *}$ & .049 & 5.071 & .000 & 1.802 \\
\hline $\operatorname{lnCC}$ & $.540^{* \star \star}$ & .082 & 6.586 & .000 & 2.672 \\
\hline InFC & $.179^{* \star \star}$ & .042 & 4.260 & .000 & 1.790 \\
\hline InRISK & $-.069^{* * *}$ & .022 & -3.202 & .002 & 1.360 \\
\hline $\operatorname{InTA}$ & $1.007^{* * *}$ & .054 & 18.582 & .000 & 2.675 \\
\hline $\operatorname{InBR}$ & $-.086^{* *}$ & .043 & -2.010 & .048 & 1.710 \\
\hline $\ln G R$ & $.0388^{*}$ & .021 & 1.865 & .066 & 1.250 \\
\hline R-squared & .826 & & & & \\
\hline Adjusted R-squared & .813 & & & & \\
\hline F-statistic & 56.202 & & & .000 & \\
\hline Chow-test & 53.792 & & & .000 & \\
\hline Hausman-test & .000 & & & 1 & \\
\hline LM-test & 26.719 & & & .000 & \\
\hline Jarque-Bera test & .724 & & & .613 & \\
\hline Breusch-Pagan test & .022 & & & .882 & \\
\hline H-statistics & .965 & & & & \\
\hline Wald test $(H=0)$ & 125.753 & & & .000 & \\
\hline Wald test $(H=1)$ & .3882 & & & .052 & \\
\hline Equilibrium test $(\mathrm{E})$ & 4.451 & & & .038 & \\
\hline
\end{tabular}

Note: ${ }^{* * *},{ }^{* *}$, and ${ }^{*}$ denote significant at $1 \%, 5 \%$, and $10 \%$ level of significance.

Therefore, the outcomes of the study showed that the Nepalese banking industry was running under the perfect competition during the study period. Concerning the regressors in the reduced form model, the results showed that the input prices of labor costs $\left(\alpha_{1}=.246, \mathrm{p}<.01\right)$, capital costs $\left(\alpha_{2}=.540, \mathrm{p}<.01\right)$, and funding costs $\left(\alpha_{3}=.179\right.$, $\mathrm{p}<.01)$ were significantly and positively associated with the interest income of Nepalese CBs. However, the bank's specific factors RISK $\left(\beta_{1=-.069, p}<.01\right)$, and BR $\left(\beta_{3=}-.086\right.$, $\mathrm{p}<.05)$, were negatively related to the interest income. But, the size of the firm $\left(\beta_{2}=1.007, \mathrm{p}<.01\right)$, which was measured by the natural logarithm of total assets was positively related to the interest income. Finally, the macroeconomic variable GDP growth rate $\left(\gamma_{1=} .0388, \mathrm{p}<.1\right)$, is positively associated with interest income and statistically insignificant at $5 \%$ level, but significant at the $10 \%$ level.

\subsection{Equilibrium Test Results and Sensitivity Analysis}

The basic notion of the P-R model is that the sum of the elasticity of input prices should be jointly zero (i.e. $\alpha_{1}$ $\left.+\alpha_{2}+\alpha_{3}=0\right)$ in the long-run. The result of Wald statistic $[\mathrm{F}(1,82)=4.451, \mathrm{p}=.038]$ concerning the equilibrium test using lnROA as a regressand showed that the market was in equilibrium at the $1 \%$ significance level. Therefore, the result of the Wald-test showed that the Nepalese banking market was in long-run equilibrium and was valid to continue to investigate the extent of bank market competition using the P-R approach. Further, we examined the state of market equilibrium on OLS and FEM. The outcomes of both models give the same conclusion. The result of Wald statistic $[F=2.062(1,82), p=.1549]$ of pooled OLS showed that the market is in equilibrium condition during the study period.

Similarly, the outcome of Wald statistic $[\mathrm{F}=3.731$ (1, $74), p=.057]$ of the FEM showed that the market is in equilibrium condition during the study period. The long-run market equilibrium finding was matching to the outcomes obtained by Gajurel and Pradhan (2012) and Neupane (2016) for Nepalese banking. However, this result is incompatible with the study of Rakshit and Bardhan (2020) in the Indian context. Further "The market equilibrium test is conducted in order to draw inference on the impact of the explanatory variables on ROA" (Rakshit \& Bardhan, 2020). The positive slops of LC and CC (.273 and .388) show that LC and CC have a direct effect on ROA in the long-run. However, the negative slope of FC (-.141) indicates that FC inversely affects the ROA in the long-run, but statistically insignificant (see Table 6). 
Prem Bahadur BUDHATHOKI, Chandra Kumar RAI, Arjun RAI I

Table 6: Pooled OLS, Fixed Effects Model and Random effect Model

\begin{tabular}{|c|c|c|c|c|c|c|}
\hline \multirow[t]{2}{*}{ Variables } & \multicolumn{2}{|c|}{$\begin{array}{c}\text { Pooled OLS } \\
\text { (Inll as regressand) }\end{array}$} & \multicolumn{2}{|c|}{$\begin{array}{l}\text { Fixed effect Model } \\
\text { (Inll as regressand) }\end{array}$} & \multicolumn{2}{|c|}{$\begin{array}{l}\text { Random effect Model } \\
\text { (InROA as regressand) }\end{array}$} \\
\hline & Coefficient & $p$-value & Coefficient & $p$-value & Coefficient & $p$-value \\
\hline InLC & $.181^{* * *}$ & .001 & $.365^{\star \star *}$ & .000 & .272 & .043 \\
\hline $\operatorname{lnCC}$ & $.555^{\star \star *}$ & .000 & $.384^{\star \star *}$ & .000 & .388 & .085 \\
\hline $\operatorname{lnFC}$ & $.181^{* * *}$ & .001 & $.136^{* * *}$ & .004 & -.141 & .207 \\
\hline InRISK & $-.077^{\star * *}$ & .002 & -.034 & .189 & -.040 & .494 \\
\hline $\operatorname{lnTA}$ & $1.023^{* \star *}$ & .000 & $.890^{* * *}$ & .000 & .001 & .994 \\
\hline $\ln B R$ & -.055 & .216 & $-.254^{* * *}$ & .006 & -.351 & .004 \\
\hline InGR & $.045^{*}$ & .093 & .032 & .134 & -.031 & .574 \\
\hline R-squared & .838 & & .911 & & .355 & \\
\hline Adjusted R-squared & .824 & & .893 & & .300 & \\
\hline F-statistics & 60.719 & .000 & 50.521 & .000 & 6.446 & .000 \\
\hline H-statistics & .917 & - & .885 & & & \\
\hline Wald test $(\mathrm{H}=0)$ & 68.538 & .000 & 68.674 & .000 & & \\
\hline Wald test $(\mathrm{H}=1)$ & .557 & .458 & 1.169 & .283 & & \\
\hline Equilibrium test $\left(\alpha_{1}^{\prime}+\alpha_{2}^{\prime}+\alpha_{3}^{\prime}=0\right)$ & 2.062 & .1549 & 3.731 & .0572 & & \\
\hline
\end{tabular}

Note: ${ }^{* *},{ }^{* *}$, and ${ }^{*}$ denote significant at $1 \%, 5 \%$, and $10 \%$ level of significance.

Similarly, BR (expansion of bank branches) negatively affects the ROA of the banks in the long-run. Other regressors such as RISK (-.040) and GR (-.031) inversely affect the ROA but statistically insignificant. Finally, a positive slope of TA (.001) shows the direct effect on ROA; however, statistically insignificant.

\section{Discussion}

The study carried out by Gajurel and Pradhan (2012) revealed a monopolistic market behavior in the Nepalese CBs over the study period 2001-2009. A similar result has led to the study of Neupane (2016). However, this study depicted the exciting fact that the competitive condition of the Nepalese CBs has shifted from monopolistic competition to perfect competition. The $\mathrm{H}$-statistic of the Nepalese banking sector is .965 , which was close to the state of perfect competition. This result was matching to the findings of Hall and Simper (2013) and Kumar and Gulati (2019). It was incompatible with the findings of Gajurel and Pradhan (2012); Neupane (2016); Akthan and Mosood (2010); Biekpe (2011); Fosu (2013); Simatele (2015); Apergis (2015); Sakar and Sensharma (2016); Barros and Mendes (2016); Tan (2016); Tihir et al. (2016); Rakshit and Bardhat (2020).
The outcomes of the reduced-form revenue model showed that the input prices have a positive and significant association with interest income. The first regressor LC revealed that a high labor cost paid by banks to their employees increases the bank's interest income. This result is harmonious to the prior empirical findings of Akthan and Mosood (2010); Biekpe (2011); Gajurel and Pradhan (2012); Neupane (2016); Fosu (2013); Simatele (2015); Apergis (2015); Sakar and Sensharma (2016); Barros and Mendes (2016); Tan (2016); Tihir et al. (2016); and Rakshit and Bardhan (2020). This empirical evidence elucidated that a higher level of financial benefit increases employees' morale, dedication, and loyalty to the organization and increase the overall efficiency and productivity of the banks. As a result, it increases banks' interest income. The second regressor CC revealed that high investment in capital assets increases the bank's interest income.

This result is in tune with the prior empirical findings of Gajurel and Pradhan, (2012); Neupane (2016); and Rakshit and Bardhan (2020). However, this result is differing with the findings of other earlier studies of Fosu (2013), and Hall and Simper (2013). This fact cleared that high investment in the latest technology enhances the efficiency and effectiveness of the banks, which in turn, increases interest income. Likewise, 
the third regressor FC showed that the higher funding cost increases the banks' interest income. This result is agreeing to the former empirical findings of Gajurel and Pradhan (2012); Neupane (2016); Akthan and Mosood (2010); Biekpe (2011); Fosu (2013); Simatele (2015); Apergis (2015); Sakar and Sensharma (2016); Barros and Mendes (2016); Tan (2016); Tihir et al. (2016); and Rakshit and Bardhan (2020). However, this result is conflicting with the findings of the past study of Hall and Simper (2013).

This finding elucidated that a higher deposit interest rate attracts more deposits and provides ground for investment in securities and loan and advances, which, in turn, a higher interest income to the CBs. The coefficient of banks' specific factor RISK showed that a higher level of loan loss provision decreases the banks' interest income. This outcome demonstrated that a higher level of non-performing assets represents the deterioration of loan quality and default loss, which, in turn, lower performance of CBs. This result is alike to the previous empirical findings of Biekpe (2011) and Tihir et al. (2017). However, this result is distinct with the findings of other erstwhile studies of Fosu (2013); and Apergis (2015). The coefficient of another banks' specific factor TA showed that a higher level of assets gives the benefit of economies of scale and can get funds at a lower interest rate through their reputation. This result is similar to the previous empirical findings of Gajurel and Pradhan (2012); Fosu (2013); Apergis (2015); Barros and Mendes (2016); Neupane (2016); Tan (2016); and Rakshit (2020). However, this result is in contrast with the findings of other previous studies Tihir et al. (2016). The last banks' specific factor BR, a proxy of expansion of business (consumer access to finance) showed that a higher level of the number of bank branches reduced the banks' interest income.

This finding clarified the fact that a larger number of bank branches decreased the quality of the loan, which directly increase the default loss and reduce the banks' interest income. This result is analogous to the previous empirical findings of Akthan and Mosood (2010). However, this result is incompatible with the findings of the former study of Hall and Simper (2013). Finally, the slope of macroeconomic variable GR showed that a higher economic growth rate posits a higher interest income to the CBs. This result is identical with the previous empirical findings of Fosu (2013). However, this result is contrary with the findings of other forgoing studies of Akthan and Mossood (2010). This fact elucidated that a higher economic growth fosters investment opportunity to the CBs and enhance the banks' interest income.

\section{Conclusion}

This study uses the P-R model to check out the state of competition in the Nepalese CBs using the panel data from 2010-2019. The E-statistic of equilibrium test reveals that the Nepalese CBs market is in long-run equilibrium, and elucidated that the input costs do not affect the ROA in a long-run in the Nepalese CBs market. Further, the hypothesis of perfect competition $(\mathrm{H}=1)$ has been accepted by the Wald test result; nevertheless, the supposition of monopoly and monopolistic competition has been rejected in the Nepalese banking industry. This result demonstrates that contestability in the Nepalese CBs has shifted from monopolistic competition to perfect competition. The results of the reduced-form equation showed that the input prices have a significant determinant of bank revenue, which is measured by interest income.

Similarly, the bank-specific factors RISK, measured by provision for loan losses over total loan and advances and BR, a proxy of expansion of business, are significant determinants of bank's revenue and shows inverse links between regressand. Likewise, another bank's specific factor TA, a proxy of the size of banks, revealed that the positive and significant effect on banks' interest income. Finally, the macroeconomic variable GR, proxy of economic growth rate has a positive impact on banks' revenue. The findings of the study provide a fascinating insight into the banks' competition in Nepal. The paradigm shift from monopolistic competition to perfect competition brings efficiency and stability in the financial system of Nepal.

Nonetheless, this study shows some limitations. First, this study covers the only non-structural method, that is, the P-R model. Second, this study employed the reduced-form equation by taking an unscaled II as a regressand. Finally, this study uses REM to measure the competitive condition of the Nepalese banking industry. Therefore, further research can be conducted either by taking the structural method or scaled reduced-from revenue equation to measure bank competition in Nepal.

\section{References}

Ahamed, M. M. (2017). Asset quality, non-interest income, and bank profitability: Evidence from Indian banks. Economic Modelling, 65, 1-14.

Aktan. B., \& Masood, O. (2010). The state of competition of the Turkish banking industry: An application of the Panzar-Rosse model. Journal of Business, Economics, and Management, 11(1), 131-145.

Ali Bhatti, G., \& Hussain, H. (2010). Evidence on structure conduct performance hypothesis in Pakistani commercial banks. International Journal of Business and Management, 5(9), 174-187. https://doi.org/10.5539/ijbm.v5n9p174

Al-Muharrami, S., Matthews, K., \& Khabari, Y. (2006). Market structure and competitive conditions in the Arab GCC banking system. Journal of Banking and Finance, 30(12), 3487-3501. https://doi.org/10.1016/j.jbankfin.2006.01.006 
Apergis, N. (2015). Competition in the banking sector: New evidence from a panel of emerging market economies and the financial crisis. Emerging Markets Review, 25, 154-162.

Barros, C. P., \& Mendes, Z. (2016). Assessing the competition in Angola's banking industry. Applied Economics, 48(30), 27852791. https://doi.org/10.1080/00036846.2015.1128083

Berger, A. N., Klapper, L. F., \& Turk-Ariss, R. (2009). Bank competition and financial stability. Journal of Financial Services Research, 35(2), 99-118. https://doi.org/10.1007/ s10693-008-0050-7

Biekpe, N. (2011). The competitiveness of commercial banks in Ghana. African Development Review, 23(1), 75-87. https://doi. org/10.1111/j.1467-8268.2010.00273.x

Brei, M., Jacolin, L., \& Noah, A. (2020). Credit risk and bank competition in Sub-Saharan Africa. Emerging Markets Review, May, 100716. https://doi.org/10.1016/j. ememar.2020.100716

Fang, J., Lau, C. M., Lu, Z., Tan, Y., \& Zhang, H. (2019). Bank performance in China: A perspective from bank efficiency, risk-taking and market competition. Pacific-Basin Finance Journal, 56, 290-309.

Fosu, S. (2013). Banking competition in Africa: Subregional comparative studies. Emerging Markets Review, 15, 233-254. https://doi.org/10.1016/j.ememar.2013.02.001

Gajurel, D. P., \& Pradhan, R. S. (2012). Concentration and competition in Nepalese banking. Journal of Business, Economics \& Finance, 1(1), 5-16.

Gonzalez, L.O., Razia, A., Bua, M. V., \& Setayo, R. L. (2019). Market structure, performance, and efficiency: Evidence from MENA banking sector. International Review of Economics and Finance, 64, 84-101.

Hall, M. J. B., \& Simper, R. (2013). Efficiency and competition in Korean banking. Applied Financial Economics, 23(10), 881-890. https://doi.org/10.1080/09603107.2013.776661

Homma, T., Tsutsui, Y., \& Uchida, H. (2014). Firm growth and efficiency in the banking industry: A new test of the efficient structure hypothesis. Journal of Banking and Finance, 40(1), 143-153. https://doi.org/10.1016/j.jbankfin.2013.11.031

Hou. X., Wang, Q., \& Zhang, Q. (2014). Market structure, risktaking, and the efficiency of Chinese commercial banks. Emerging Market Review, 20, 75-88.

Khan, H. H., Ghafoor, A., Qureshi, F., \& Rehman, I. U. (2018). Bank competition, financial development, and growth of financially dependent industries: Fresh Evidence from China. Global Economic Review, 47(2), 108-134. https://doi.org/10.10 80/1226508X.2018.1436458

Khan, H. H., Kutan, A. M., Naz, I., \& Qureshi, F. (2017). Efficiency, growth and market power in the banking industry: New approach to efficient structure hypothesis. North American Journal of Economics and Finance, 42, 531-545. https://doi. org/10.1016/j.najef.2017.08.004
Kumar, S., \& Gulati, R. (2019). Did the global financial crisis alter the competitive conditions in the Indian banking industry? Applied Economics Letters, 26(10), 857-865. https://doi.org/1 $0.1080 / 13504851.2018 .1502865$

Le, T. T. D., \& Diep, T. T. (2020). The effect of lending structure concentration on credit risk: The evidence of Vietnamese commercial banks. Journal of Asian Finance, Economics and Business, 7(7), 59-72. https://doi.org/10.13106/jafeb.2020. vol7.no7.059

Matthews, K., Murinde, V., \& Zhao, T. (2007). Competitive conditions among the major British banks. Journal of Banking and Finance, 31(7), 2025-2042. https://doi.org/10.1016/j. jbankfin.2006.11.009

Misra, A.K., \& Arrawatia, R. (2015). Bank Competition and efficiency: Empirical evidence from Indian market. International Journal of Law \& Management, 57(3), 217-231.

Neupane, B. P. (2016). Competition in Nepalese commercial banks. NRB Economic Review, 28(2), 75-89.

Osuagwu, E. S., \& Nwokoma, N. (2017). Empirical assessment of the competitive conduct of Nigerian banks in a postconsolidation era. Research in International Business and Finance, 41(September 2016), 412-422. https://doi. org/10.1016/j.ribaf.2017.04.051

Panzar, J. C., \& Rosse, J. N. (1987). Testing for "Monopoly" equilibrium. The Journal of Industrial Economics, 35(4), 443-456. http://www.jstor.org/stable/2098582

Rachman, R. A., Kadarusman, Y. B., Anggriono, K., \& Setiadi, R. (2018). Bank-specific factors affecting non-performing loans in developing countries: Case study of Indonesia. Journal of Asian Finance, Economics and Business, 5(2), 35-42. https:// doi.org/10.13106/jafeb.2018.vol5.no2.35

Rakshit, B., \& Bardhan, S. (2020). Bank competition in India: Revisiting the application of Panzar-Rosse model. Managerial Finance. https://doi.org/10.1108/MF-09-2019-0457

Samad, A. (2008). Market structure, conduct and performance: Evidence from Bangladesh banking industry. Journal of Asian Economics, 19, 181-193.

Sarkar, S., \& Sensarma, R. (2016). The relationship between competition and risk-taking behaviour of Indian banks. Journal of Financial Economic Policy, 8(1), 95-119.

Simatele, M. (2015). Market Structure and Competition in the South African Banking Sector. Procedia Economics and Finance, 30(15), 825-835. https://doi.org/10.1016/s22125671(15)01332-5

Tahir, M., Shah, S. S. A., \& Afridi, M. A. (2016). Assessing the nature of competition in banking sector of Pakistan. The Journal of Finance and Data Science, 2(4), 244-253. https:// doi.org/10.1016/j.jfds.2017.04.001

Tan, Y. (2016). The impact of competition on efficiency in the Chinese banking industry. In Efficiency and Competition in Chinese Banking. https://doi.org/10.1016/b978-0-08-1000748.00006-6 
Tangngisalu, J., Hasanuddin, R., Hala, Y., Nurlina, N., \& Syahrul, S. (2020). Effect of CAR and NPL on ROA: Empirical study in Indonesia Banks. Journal of Asian Finance, Economics and Business, 7(6), 9-18. https://doi.org/10.13106/jafeb.2020.vol7. no6.009
Tariq, R., Khan, M. A., \& Rahman, A. (2020). How does financial development impact economic growth in Pakistan?: New evidence from threshold model. Journal of Asian Finance, Economics and Business, 7(8), 161-173. https://doi. org/10.13106/jafeb.2020.vol7.no8.161 